\title{
FARMERS PREFERANCE FOR AGRO CHEMICALS USED FOR FOOD CROPS
}

\author{
BY \\ CHANDANI PRIYADARSHIKA \\ KUMARAPELI
}

M.Sc.

2006 


\section{FARMERS PREFERENCE FOR}

\section{AGRO-CHEMICALS USED FOR FOOD CROPS}

By

CHANDANI PRIYADARSHIKA KUMARAPELI

Thesis submitted to the University of Sri Jayewardenepura for the award of the degree of Master of Science in Food Science and Technology on 2006

Sri Lanka. 


\section{Declaration}

The work described in this thesis was carried out by me, under the Supervision of Prof. Arthur Bamunuarachchi and the report on this has not been submitted in whole or in part to any University or any other institution for another degree or diploma.

$24-11-2006$

Date of submission

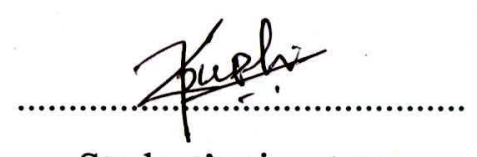

Student's signature

Project Supervisor,

Prof. Arthur Bamunuarachchi 
I here by certify that the above statement made by the candidate is true and that this thesis is suitable for submission to the University for the purpose of evaluation

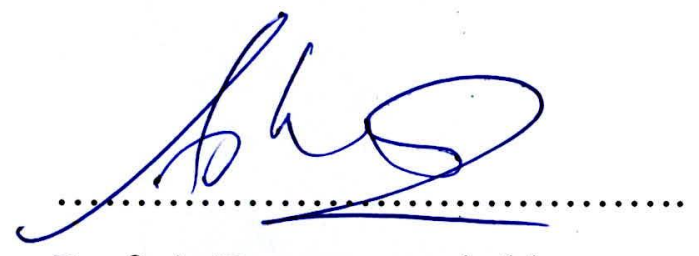

Prof. A. Bamunuarachchi

Supervisor

Department of Food Science and Technology,

University of Sri Jayewardenepura

Sri Lanka. 


\title{
Dedication
}

\author{
To \\ My Family \\ And \\ Loving teachers
}




\section{CONTENTS}

List of Figures I I

List of Tables II

Acknowledgement III

$\begin{array}{lll}\text { Abstract IV-VI } & \text { IV }\end{array}$

Chapter 01 -Introduction 1

1.1 General Introduction 1

1.2 Objectives of the study 3

Chapter 02 - Literature Review 4

2.1 Definition of pesticides 4

$\begin{array}{lll}2.1 .1 & \text { Inorganic pesticides }\end{array}$

2.1.2 Organic pesticides 5

2.1.3 Biopesticides 5

$\begin{array}{ll}2.2 \text { Classification } & 6\end{array}$

$\begin{array}{lll}2.3 \text { Effect of pesticide } & 7\end{array}$

2.4 Handling of pesticides 8

2.5 Risk of pesticides 9

2.5.1 Effects of pesticides exposure on the risk of $\begin{array}{ll}\text { spontaneous abortions } & 10\end{array}$

$\begin{array}{ll}2.6 & \text { Pesticide Usage in Sri Lanka }\end{array}$

2.7 Background of Agro Chemical function in Ceylon

$\begin{array}{lr}\text { Petroleum Corporation } & 12\end{array}$

2.8 Economic and marketing Information on Pesticides

in Sri Lanka $\quad 12$ 
2.9 Marketing 15

2.9.1 Marketing Survey 16

2.9.2 Methods used in marketing research 17

$\begin{array}{lll}2.9 .3 & \text { Questionnaires } & 17\end{array}$

$\begin{array}{ll}\text { 2.9.4 Sampling methods } & 18\end{array}$

2.9.4.1 Convenience Sampling $\quad 18$

2.9.5 Marketing Reasearch for pesticides 18

2.10 General Information of Nuwara-Eliya and

$\begin{array}{ll}\text { Kurunegala districts } & 19\end{array}$

$\begin{array}{ll}\text { Chapter 03- Methodology } & 20\end{array}$

3.1 The method of data collection $\quad 20$

$\begin{array}{ll}3.2 \text { Location } & 20\end{array}$

3.3 Sampling Procedure 21

3.4 Analysis of Data 21

Chapter 04-Results and Discussion 22

4.1 Identification of major pesticides with their brand names 22

4.2 Farmers survey on Agro Chemicals Used for food crops 23-46

$\begin{array}{ll}\text { Chapter 05-Conclusion } & 47\end{array}$

$\begin{array}{ll}\text { References } & 49\end{array}$

$\begin{array}{lr}\text { Appendix } & 50-56\end{array}$ 


\section{LIST OF FIGURES}

$\begin{array}{lll}\text { Figure 4.2.1 Age Distribution } & 24\end{array}$

$\begin{array}{lll}\text { Figure 4.2.2 Educational Background } & 24\end{array}$

Figure 4.2.3 Use of pest control methods 25

Figure 4.2.4 Methods of pest control 26

Figure 4.2.5 Nearest reason for use the pesticides) 26

Figure 4.2.6 Source of awareness of pesticides 27

Figure 4.2.7 Common media for getting information about pesticides 28

$\begin{array}{lll}\text { Figure 4.2.8 Usage of pesticides for crops } & 29\end{array}$

$\begin{array}{lll}\text { Figure 4.2.9 Insecticide application } & 30\end{array}$

Figure 4.2.10 Fungicide application $\quad 31$

Figure 4.2.11 Herbicide application 33

Figure 4.2.12 Reason for selecting any brand name 34

Figure 4.2.13 Common institution /organization 35

Figure 4.2.14 Recognition of pest and pest actions 36

Figure 4.2.15 Selection of suitable pesticides 36

$\begin{array}{lll}\text { Figure 4.2.16 Post harvest application } & 37\end{array}$

$\begin{array}{lll}\text { Figure 4.2.17 Label instruction } & 38\end{array}$

Figure 4.2.18 Mixing details of pesticides with fertilizers 39

Figure 4.2.19 Details of wearing the safety items 40

Figure 4.2.20 Feeling details while handling the pesticides (i) 40

Figure 4.2.21 Feeling details while handling the pesticides (ii) 41

Figure 4.2.22 Helpers for applying pesticides (1) 42

Figure 4.2.23 Helpers for applying pesticides (11) 42

Figure 4.2.24 Awareness of first aids 43

Figure 4.2.25 Details of abortions 44

Figure 4.2.26 Workshops for pesticides 45

Figure 4.2.27 "Ceypetco" pesticides 46

Figure 4.2.28 Availability of "Ceypetco" pesticides 46 


\section{LIST OF TABLES}

Page No

Table 2.1 The major classes of pesticides

Table 2.2 The average (and maximum) number of pesticide application per cropping season for some crops

Table 2.3 Local consumption of pesticides, 1990-1999 (tons)

Table 2.4 Major pesticides imported in 1998

Table 2.5 Comparison of consumption of several pesticides in 1990 and in 1995

Table 2.6 Population details of Nuwara-Eliya and Kurunegala districts19

Table 4.1.1 Most common insecticides in selected areas 22

Table 4.1.2 Most common fungicides in selected areas 23

Table 4.1.3 Most common herbicides in selected areas 23

Table 4.2.1 Ranking details of major pesticides in selected areas 29

Table 4.2.2 Most common brand names of insecticides in selected areas31

Table 4.2.3 Most common brand names of fungicides in selected areas 32

Table 4.2.4 Most common brand names of herbicides in selected areas 33

Table 4.2.5 Time of pesticide application 37

Table 4.2.6 Pre-harvest intervals 37

Table 4.2.7 Civil status of farm members 44 


\section{ACKNOWLEDGEMENTS.}

I express my deepest gratitude and respect to my project supervisor, Prof. Arthur Bamunuarachchi, Professor of Applied chemistry, Department of Food Science and Technology, University of Sri Jayawardenapura, for the invaluable counseling and guidance given to me always to make the research a success.

I gratefully acknowledge the valuable assistance of the Deputy General ManagerAdministration, Mr.Cyril Suduwella and Manager of the Agro-Chemical Function, Mr. A.Lambias in Ceylon Petroleum Corporation Sri Lanka.

I gratefully acknowledge the interest and valuable guidance of the Head of the Department, Food science and Technology and Coordinator of the Food Science and Technology program, Dr. K.K.D.S.Ranaweera and other academic staff of the department of Food Science and Technology and the department of Chemistry for this project.

I wish to record my gratitude to field officers and all the staff members of AgroChemical function for helping me in many ways for collecting the data.

I take this opportunity to thank all the non-academic staff of the department of Food Science and Technology for their help in numerous ways.

My special thanks are due to all my friends of the Ceylon Petroleum Corporation for their most helpful assistance in many ways.

I dearly express my appreciation to all my colleagues, who supported me in various aspects. In conclusion I am grateful to my beloved husband, parents and relations for the valuable advise assistance and encouragement given without which this report would not have been completed in this manner. 


\title{
FARMERS PREFERENCE FOR
}

\section{AGRO-CHEMICALS USED FOR FOOD CROPS}

\section{Chandani Priyadarshika Kumarapeli}

\begin{abstract}
The vast majority of Sri Lankans especially those who live in rural areas depend on agriculture for their livelihood and chemical pesticides and fertilizers are playing a vital role with farming nowadays.

Therefore the rate of adoption of new technologies using pesticides, chemical fertilizer was increasing very rapidly. The survey presents possible information about the pesticides and their benefits as well as risk factors, especially health aspects and the competitive market and farmers preferences with a great interest.
\end{abstract}

The survey consisted of two major parts and it included mainly a preliminary identification and a comparative study. The preliminary data were collected by inspecting the open market, interacting with Agrigarien office's sales centers, reputed company or corporations involving in agrochemical business and classified by their trade name , brand name and the active ingredient and inspecting of wether it is a solid, liquid or an emulsifier.

Comparative study was a totally farmer's survey and it was carried out by the completed questionnaire and the questionnaire was designed to collect relevant information from the farmers on lifestyle information, behaviour in the field, pesticide usage, competitive products of pesticides, medical history of their family and etc.

The study was carried out in Nuwara-Eliya and Kurunegala districts and for conveinience of sampling, the farmer who is available was questioned. 
The two types of analysing methods were applied to interpret the results and in qualitative analysis, researcher finalized the responses received and in quntitative analysis, researcher supervised and tabulated the results obtained.

The survey results show that the number of different product range under the major pesticide classes such as insecticide, fungicide and weedicide and it was identified according to their active ingreedents. Most of them were available as emulsifier concentration or as wetable powder in the market place.

Most of the farmers were identified in the age group between 30 to 50 and educational background of farmers was found to be rather low. Most of them were using chemical pesticides to contol or kill the pests and the most were cosidering the quick reaction of chemical pesticides than other reason. The most common way of awareness of pesticides was recorded as from sellers information and the formal information source was recorded as radio.

The results show that, herbicides are the widely used pesticide in selected areas and the results revealed that majority of farmers were using glyphosate category weedicide. Most common insecticide category was carbofuran and the mostly used fungiside category was found as mancoseb.

According to multiple responses, most of them responded that price was the main considerable one for selecting any pesticide. The majority of the farmers had knowledge about correct pesticides for relevant pest action and the results suggest that the farmers often ignored technical recommendations and they were using pesticides by their own experience without considering the suitable time duration even. 
Majority of farm families was with 3-5 members and contribution to the labor by the family members was identified as an important factor. It was very difficult to find out the actual situation relating chemical pesticides with spontaneous abortions.

The problem to be examined within this study was to analyze some of the factors that can have an impact on pesticide prices and product availability. Most of the time farmers are concerned about the price, sales discounts and the credit and loan facility while they choose any brand of pesticides in selected areas. 


\section{Chapter 1 \\ INTRODUCTION}

\subsection{General Introduction}

Sri Lanka is an Island in the south Asian region and geographically situated in the Indian Ocean off the cost of southern India. It is an agricultural country with a population of 19.5 million people and has a wealth of fresh vegetables, fruits, and excellent spices and also produces the best teas in the world ${ }^{1}$.

Agriculture is mainly spans in four sectors in Sri Lanka and they are paddy cultivation, vegetable and other field crops, plantation crops and livestock farming. The agriculture sector accounts for nearly 22 per cent of foreign exchange earnings, predominantly from plantation crops such as tea, rubber and coconut, which cover an extent of 889,000 hectares ${ }^{3}$. Rice being the staple food, and rice cultivation is done during the major season (maha) and is done during the minor season (yala). Before two three decades the population in Sri Lanka was relatively small and hence food requirements remained at a lower level. Cultivation was done less intensively and usually only during one season. Food security was the principal need of the people in Sri Lanka. Under such a system of cultivation, there was little possibility for pests to multiply and spread. Further, traditionally grown crop varieties were well adapted to the environment, and hence pest attack was negligible.

Farmers in Sri Lanka have had cultural, mechanical and physical methods of pest control in the past, or practiced no pest control. Pesticide application was limited, because the yield potential of traditional varieties was too low to justify additional investments. Many paddy lands were cultivated only during the main wet season. In addition, they incorporated a lot of organic matter such as straw, lopping from hedges 
and fences, dung and other animal wastes to the soil. Once the paddy crop was harvested cattle were allowed to feed on the stubble and weeds and that helped not only in destroying weeds but also in enriching the soil in the most natural way by adding considerable amount of cow dung to the land.

With the increase in population, it is necessary to adjust the challenge of increasing food supply to feed a growing population. More land was brought under the plough and there was year round cultivation which provided food almost throughout the year for pests. With the developments of methods to destroy pests, natural pest resistance of these crops had disappeared. Pesticides and chemical fertilizers were recommended as a package to exploit the high yield potential of new varieties. New technologies developed were attractive to farmers and easy to practice. Therefore the rate of adoption of new technologies using pesticides, chemical fertilizer was very rapid. People were encouraged to cultivate every bit of arable land.

As they were more vulnerable to weeds, proper weed control methods had to be adopted. Manual weeding was laborious, resulting in high cost of cultivation. Consequently, chemical weedicides became more convenient and cheap. Same situation happened to the insect and fungi controlling systems in agricultural sector.

In the face of a growing human population and increased urbanization, demand for pesticides did rise. Farmers must increase yields on increasingly fewer farm acres. Farmers use pesticides to protect crops from insect pests, weeds and fungal diseases while they are growing, prevent rats, mice, flies and other insects from contaminating foods whilst they are being stored, by stopping food crops being contaminated by fungi and expect a high yield. Sometimes they do not worry about the safeguard of human health as well as their safeguard during the application of pesticides. 